\title{
Engellilerin Toplumsal Entegrasyonunda Siyasal Temsil Üzerine Bir Deneme: Türkiye Özürlüsü ile Mutludur Partisi
}

\author{
DOI: 10.26466/opus.891666 \\ * \\ Ersin Eraslan* - Melih Cosgun ** \\ ** Doktora Öğrencisi, İstanbul Ünivesitesi, Çalışma Eko. ve End. İliş. Bölümü. İstanbul/Türkiye \\ E-Posta: ersin eraslan@ohu.edu.tr ORCID: 0000-0003-0800-8966 \\ ** Dr. Öğr. Üyesi, Niğde Ömer Halisdemir Üniversitesi, NSBMYO, Hukuk Bölümü. Niğde/Türkiye \\ E-Posta: melihcosgun@ohu.edu.tr \\ ORCID: $\underline{0000-0003-0017-0600}$
}

\section{Öz}

Bu çalışmanın amacl, Türkiye'de engellilerin sosyal hakları bağlamında siyasal katılım ve siyasal temsilin toplumsal/siyasal hayattaki yerini belirlemektir. Engellilerin toplumsal yaşamdaki yerini açıklama ve anlamlandırma çabaları neticesinde ortaya atılan "engelliliğe yönelik temel yaklaşımlar" çalışmanın teorik çerçevesinin bir ayağını oluşturmaktadır. Bununla birlikte teorik kısmın diğer ayağı ise insan hakları ve siyasal temsil kavramlarının hangi bağlamda ele alındığıdır. Bu makale engelliliği açıklamaya yönelik temel yaklaşımlardan olan "insan hakları modeli" üzerine inşa edilen düşünce sistemine Jellinek'in "aktif statü hakların”" da eklemlendirmeyi önermektedir. Buna ek olarak çalışmada, siyasi partilerin işlevleri ile insan hakları modeli arasında bir rabıta kurularak siyasal temsilin engellilerin toplumsal entegrasyonunda önemine ve gerekliliğine dair bir anlatıya yer verilmiştir. Batı'da yer alan güncel temsil örneklerinden yola çıkarak "küçük parti" tanımlaması üzerinden "Türkiye Özürlüsü ile Mutludur Partisi" deneyimine de çalışma içerisinde yer verilmiştir. Çalışmanın temel iddiası engellilerin toplumsal entegrasyonunda siyasal katılım ve temsilin eğitim hakkl, sağllk hakkl, işsizlik sorunu gibi konularla ilişkili olup, bir o kadar da önemli olduğudur.

Anahtar Kelimeler: Engelliler, Engelli Hakları, Aktif Statü Hakkı, Siyasal Temsil, Türkiye Özürlüsü ile Mutludur Partisi. 
ISSN:2528-9527

E-ISSN : 2528-9535

YIl Year: 11

Cilt Volume: 17

Sayı Issue :37

Uluslararası Toplum Araştırmaları Dergisi International Journal of Society Researches

Haziran June 2021

Makalenin Geliş Tarihi Received Date: 05/03/2021

Makalenin Kabul Tarihi Accepted Date: 21/04/2021

\title{
An Essay on Political Representation in Social Integration of Disabled People: Turkey Happy with Disabled Party
}

\begin{abstract}
The purpose of this study, in the context of the social rights of people with disabilities in Turkey, political participation and political representation of the social / political life is to determine the location. The "basic approaches to disability", which has been put forward because of the efforts to explain and make sense of the place of the disabled in social life, constitute one leg of the theoretical framework of the study. However, the other leg of the theoretical part is the context in which the concepts of human rights and political representation are handled. This article proposes to articulate Jellinek's "rights to active status" to the thinking system built on human rights put forward by the basic approaches to explain disability. In addition, by establishing a nexus between the functions of political parties and the human rights model, a narrative about the importance and necessity of political representation in the social integration of the disabled is included. Based on the current sample represented in the West "small parties" out to define "Turkey Happy with Disabled Party" experience is also included in the study. The main claim of the study is that political participation and representation are as important as issues such as the right to education, the right to health, and the problem of unemployment in the social integration of the disabled.
\end{abstract}

Keywords: Disabled People, Disability Rights, Active Status Rights, Political Representation, Turkey Happy with Disabled Party. 


\section{Giriş}

Toplumsal düzen içerisinde engelli vatandaşların pek çok farklı sorunla karşı karşıya olduğu bilinmektedir. Engellilerin sağlık hizmeti alırken yaşadığı sorunlar, eğitim süresince karşılaştıkları zorluklar, çalışmak istediklerinde emek piyasasının dışına itilmeleri en temel ihtiyaçların karşılanmasında dahi karşılaştıkları sıkıntılardır. Başta sivil toplum örgütleri olmak üzere çeşitli organizasyonların yardımlarıyla bu sorunlar aşılmaya çalışılmaktadır. Diğer yandan tarihsel sürece bakıldığında toplumu oluşturan farklı grupların zamanla çıkarları doğrultusunda bir araya gelip yöneticilerden/devletten/hükümetten düzenlemeler yapılmasını istemiş oldukları görülmektedir. Bu bağlam ise bizi, Mouffe'un da üzerinde durduğu üzere, her toplumsal nesnelliğin nihayetinde politik olduğu (Mouffe, 2001, s.32) gerçekliğine götürmektedir. Zira toplumu oluşturan sinıfların ve grupların kendi taleplerinin yerine getirilmesi için, pek çok zaman daha güçlü olmak adına, vakıf, dernek, sendika ve siyasi parti gibi örgütlenme biçimleriyle bir araya geldiği görülmektedir. Bu noktadan hareketle, çalışmanın temel problematiği; engellilerin temsili düzleminde siyasal temsiline ilişkin bir eksikliğin var olduğu üzerine kurgulanmıştır.

Bu çalışma, engellilerin sahip olduğu ve fakat geliştirilmesi gereken sosyal haklara siyasal temsili hakkının da eklemlendirilmesini önermektedir. Günümüzde engelli vatandaşların toplumsal entegrasyonun da ağırlıklı olarak eğitim, sağlık ve ekonomik sorunlara odaklanıldığı su götürmez bir gerçek olarak karşımıza çıkmaktadır. Bu gerçekliği göz ardı etmeden fakat hâlihazırda dezavantajlı gruplar içerisinde yer alan engellilerin bu sorunlarına yönelik iyileştirme çabaları onların negatif ve pozitif statü hakları gereği üzerine yapılmalıdır. Diğer bir ifadeyle bu iyileştirme çabaları bir lütuf değil aksine bir zorunluluktur. Çalışmada eksikliğini vurgulamayı amaçlanan olgu engellilere yönelik hakların dile getirilebilmesi ve uygulama alanı bulabilmesi adına daha etkin bir siyasal temsil mekanizması oluşturulması gerekliliği üzerinedir. Bu bağlamda aktüel olarak, çalışmalarına devam eden engelliler ile ilişkili dernekler ve vakıflar temsilin bir kısmını oluşturmaktadır. Fakat bu oluşumlar yeteri ve etkili organizasyonlara dönüştürülememektedir. Nitekim engellilerin işsizlik, eğitim ve sağlık hizmetine ilişkin mevcut sosyal dışlanma sorunları bu durumun bir göstergesi niteliğindedir. Bu çerçevede çalışmanın amacı toplumda azımsanmayacak sayıda olan engellilerin siyasal temsilinin 
ne denli olduğunu ortaya koymaktır. Bu bağlamda Türkiye Özürlüleri ile Mutludur Partisi deneyimine çalışmada yer verilmiş olup parti kapatma davası ve akabinde kendisini feshetme ile neticelenen bu temsil sorunu da çalışmada ayrıca ele alınmıştır.

\section{Kavramsal Olarak Engellilik}

Farklı ülkelerde, farklı zamanlarda, farklı yaklaşımların sergilendiği ve farklı tanımlamaların yapıldığı bunun sonucunda kapsamının da net olarak belirlenemediği engelliliğin genel geçer bir tanımın yapılması epey güçtür. Öyle ki insanlık tarihi kadar eski olan engellilik meselesi bünyesinde başta biyolojik, psikolojik ve toplumsal bakış açısı gibi pek çok muhteviyatı barındırması, meselenin olgusal düzlemini genişletmekte ve engelliliği kompleks bir yapıya büründürmektedir. Bu durum ise engelliliğin sakat, özürlü, yetersizlik ve bozukluk gibi pek çok kavramla izah edilmesi sonucunu doğurarak meselenin kavram karmaşası içerisinde kalmasına neden olmaktadır.

Bahsi geçen kavramların birbirlerinin yerine kullanılmasının en önemli nedeni kavram tercihlerinde belirli bir tutarlılık ve istikrarın olmamasidir. Keza uluslararası sözleşmeler ve düzenlemelerin resmi çevirilerinde dahi bu tutarsızlık gözlemlenmektedir. Nitekim Türkiye'de, uluslararası çevirilerde 1990'lı yıların sonuna değin "sakat" terimi yaygın olarak kullanılmışken bu tarihten sonra "özürlü" terimi ve nihayet 2006 yılında ilk defa uluslararası bir sözleşme olan "Engelli Haklarına İlişkin Sözleşme" (EHISS) adlı düzenlemenin çevirisinde "engelli" terimi kullanılmıştır (Şişman, 2012, s.71). Türkiye'de 2013 yılına değin yürürlükte olan yaklaşık yüz kanunda hem sakat hem özürlü hem de engelli terimine rastlamak mümkünken 6462 sayılı kanunla bu ifadelerin hepsinin "engelli" terimi ile değiştirilmesi sağlanarak tutarlı bir zemin hazırlanmaya çalışılmıştır. Buna rağmen 1982 Anayasası'nda ve Türkiye Sakatlar Derneği, Altı Nokta Körler Derneği gibi birçok sivil toplum kuruluşların isimlerinde sakat ve özürlü kavramları yerini muhafaza etmektedir. Diğer yandan belirtmek gerekir ki bu durum sadece Türkiye ve Türkçe özelinde yaşanmamakta diğer ülkelerde de engellilik yerine birçok farklı kavramın kullanıldığı görülmektedir. Öyle ki İngilizce'de "handicap”, "defective", "disabled", "with obstacles" Almanca 'da "verkrüppelt", "faul" gibi pek çok terimin engelli, özürlü, sakat anlamında kullanıldığı bilinmektedir (Şişman, 2012, 70). Esasen bu noktada Dünya Sağlık Örgütü (WHO)'nün 1980 
y1lında geliştirdiği üç kademeli model bahsi geçen terimler arasındaki farkl1lıkları ortaya koyabilmektedir. Modele göre engellilik süreci meydana gelen kaza/hastalık nedeniyle kişinin bünyesinde bir sakatlık/bozukluğun başlamasından sonra kişiye tıbbi, sosyal ve mesleki rehabilitasyon hizmeti verilmezse veya verildiği halde kişinin etkinliğinin sınırlı kalması halinde geçici sakatlığın özürlülüğe dönüştügü bir durum yaşanmakta ve son aşama olarak özürlü kişi yetersiz sosyo-ekonomik imkanlar sebebiyle sosyal hayattan dışlandığı takdirde engellilik durumu yaşanmaktadır. Görüldüğ̈̈ üzere modelde engellilik son aşamada ortaya çıkmaktadır (Seyyar, 2015, s. 27).

Engellilik kavramına genel çerçevede bir değerlendirme yapılmak istendiği takdirde; toplumun bakış açısındaki ve tutumundaki değişimler, teknolojide yaşanan gelişmeler, uluslararası sözleşmeler gibi yeni gelişmelerin kavrama dinamizm kattığının ve dünya genelinde kavrama ilişkin olarak paradigma değişimlerine vesile olduğunun bilinmesi elzem bir nitelik taşımaktadır. Bu bağlamda kavramsal olarak engelliliğin anlaşılması maksadıyla engelliliğin genel geçer bir tanımının yapılması gibi engellilik meselesine statik bir yaklaşım yerine dinamik bir yaklaşım sergilemenin daha yerinde olacağını söylemek yanlış olmayacaktır. Bu noktadan hareketle engellilik meselesinin kavramsal niteliğini toplumsal yaklaşımlarla ortaya koymaya çalışan "ahlak modeli", "tıbbi model", "sosyal model" ve "insan hakları modeli" şeklinde engelliliğe yönelik temel yaklaşımların dile getirilmesinin yanında bu yaklaşımlarla sebep-sonuç ilişkisinin kurulması, engelliliğin kavramsal zeminini ortaya konulması açısından oldukça yararlı olacaktır.

\section{Engelliliğe Yönelik Temel Yaklaşımlar}

Engellik kavramı ancak engellilerin içinde yaşadığı toplumun engelliliğe yönelik bakış açısının ne olduğunun ortaya konulması ile daha iyi anlaşılabilecek bir husustur. Öyle ki engellileri aciz ve toplumsal yük olarak gören bir bakış açısıyla, engelliliği, engelli ve ailesinin meselesi dışında toplumun tamamını ilgilendiren bir durum olarak gören diğer bir yaklaşım kıyasland1ğında ciddi farklılıkların olacağı şüphe götürmemektedir.

Kavramsal dinamikliği ve paradigma değişimini gözler önüne seren engelliliği açıklamaya yönelik bu temel yaklaşımlar, engelliliğin olgusal yapısını ortaya koyar bir nitelik arz etmektedir. Bu kapsamda temel yaklaşımlar; 
toplumda tutum ve yargılardaki değişimlerin etkinliği, hukuksal zeminin yapısı, kamusal hizmetlerin yönü ve erişebilirliği, yetersizlikler eksenli dar tanımlamalar yerine engelliliğin olgusal düzlemini oluşturan dinamik yapılar olarak değerlendirilebilir. Başka bir deyişle bir ülkedeki engelliliğe yönelik toplumsal zihniyet, hukuksal zemin ve kurumsal yapı engelliliğin kavramsal yapısını ortaya koymaktadır. Öyle ki, EHİ' in giriş bölümündeki (e) bendinde, "engelliliğin gelişen bir kavram olduğunu ve engellilik durumunun, sakatlığı olan kişilerin topluma diğer bireyler ile eşit koşullarda tam ve etkin katılımını engelleyen tutumlar ve çevre koşullarının etkileşiminden kaynaklandığı" şeklindeki ifadesi ile kavramın dinamikliğinin yanı sıra çevre koşuları ve toplumsal tutumlara atıfta bulunulmuştur. Bu bağlamda engelliliği, engellilerin içinde yaşadığı toplum ve zamana göre yansitan modellerin en yaygın olanları Batı tarihi ekseni içinde alt başlıklar halinde kronolojik açıdan sıralanarak yansitılmıştır.

\section{Ahlak Modeli}

Batı tarihinde Antik Dönem'den Feodal Dönem'e değin toplum, engelliliğe yönelik pek olumlu bir tutum takınmamasının yanında engelliliği ilahi bir ceza olarak niteleyen bir yaklaşımı benimsemiştir. Özellikle Antik Yunan ve Roma Dönemi'nde engelli çocukların varlığı, ebeveynlerinin günahlarının sonucu olarak açıklanmaya çalışılmış ve toplumun engelli bireye yardım etmesi tanrıların gazabı ile sonuçlanması muhtemel bir yaklaşım olarak değerlendirilmiş olup bu tutumun nihai sonucu olarak engelliler şehrin diş bölgelerinde yalnızlığa ve ölüme terkedilmiştir. Feodal Dönem'de ise Hristiyanlıkta Katolik Kilisesi'nin egemen olduğu Orta Çağ'ın ilk dönemlerinde engellilik toplum tarafından utanç verici, tiksinilen ve acınası bir durum olarak görülmüş olup Orta Çağ'ın geç dönemlerinde ise engellilik, cadılık ile ilişkilendirilmiş ve binlerce engelli birey yakılarak öldürülmüştür. Ahlak modellinin temelini oluşturan bu dönemin toplumsal yaklaşımın kaynağında engelliliğin nedeni olarak ilahi ceza bulunmaktadır (Taşcı, 2018, s. 121-5). Her ne kadar günümüzde bu anlayışın tamamen terkedildiği dile getirilse de toplumsal bakış açısında olmasa bile bu anlayışın bireysel düşüncelerde varlığını devam ettirdiğini söylemek yanlış olmayacaktır. Öyle ki bakıma muhtaç engelli bireylerin yaşama hakkının masaya yatırıldığı Bio-Etikçi Peter Singer öncülüğündeki tartışmalar, Çin'de 1995'ten beri yürürlükte olan, engelli doğması 
muhtemel bebeklerin kürtaj yoluyla alınmasını mecbur kılan" "Irk Temizliği ve Koruyucu Sağlık Kanunu" (Seyyar, 2015, s. 90-1) gibi gelişmeler, bu durumun birer göstergesi niteliğindedir.

\section{Tibbi Model}

Tibbi Model veya yaygın ismi ile Medikal Model'in başlangıcının klasik bilimle ${ }^{2}$ ilişkilendirilerek 1800'lere kadar gittiği dile getirilmektedir (Goodley, 2011, s. 7 akt. Taşcı, 2018, s. 140). Bu modelde engellilik normalden sapma durumu olarak ele alınarak problem, sosyal bariyerleri dikkate almadan sadece engelli kişinin bireysel tıbbi yetersizliği ile ilişkilendirilmiştir. Başka bir deyişle mesele engeli bireyin anormalitesine indirgenerek normalden sapmayı düzeltmek veya en aza indirmek için medikal tedavi ve rehabilitasyon üzerine odaklanmış bir yaklaşım söz konusudur. Bu yaklaşımda kusur, engelli bireye yüklenerek, engelli bireye çare ihtiyacında olan hasta birey olarak yaklaşılmaktadır (Gönülaçan, 2016, s. 10-1). Bu anlamda engelli bireyler hak sahibi olmaktan çok muhtaçlık zemininde alıc pozisyonundaki bireyler olarak görülmektedir. (Kökkaya, 2006, 17-8 akt. Taşc1, 2018, s. 142). Tibbi yaklaşımın her ne kadar engelli bireyler açısından en müspet amacının sağlığa yönelik olduğu dile getirilse de yaklaşımın engelli bireyi çevresinden bağımsız olarak ele alması engelliliği hastalık olarak görmesinin yanı sıra engelliler açısından damgalanma, sosyal dışlanma gibi tehditleri bünyesinde barındırmaktadır. Bu sebeple tıbbi model yaklaşımına 1960'lı yıllarda özellikle Amerika Birleşik Devletleri'nde ve İngiltere'de engelli aktivistler tarafından karşı çıkılmış ve engellilik kavramının yeniden ele alınması bağlamında sosyal model kavramının politik zemini oluşturulmuştur (Seyyar, 2015, s. 100).

\footnotetext{
${ }^{1}$ Antik Roma döneminde benzer şekilde engelli bebeğin yaşam hakkının kararı babanın elinde bulunmaktadır. Ayrıntılı bilgi için bkz. Taşcı (2008).

${ }^{2}$ Klasik bilim; geçmiş ile gelecek arasında bir simetri öngören Newton bilimi ile doğa-insan, madde-akıl, fiziksel-sosyal dünya arasında köklü ayrımların olduğunu öne süren Descartes'in Kartezyen düalizmine tekabül eden iki temel varsayım üzerine inşa edilmiştir. Bu iki varsayım 20. yüzyılın başlarında sosyal bilim metodolojine de hâkim olarak engellilik tıbbi yetersizlik anlayışı altında biyolojik problemler etrafında izah edilmeye çalışılmıştır. Ayrıntılı bilgi için bkz. Meşe, 2014, s. 79-92.
} 


\section{Sosyal Model}

1960 'l 1 y1llarda bir taraftan engellilerin toplumsal hareketi diğer taraftan akademik zeminde yürütülen faaliyetlerin sonucunda, 1970'li yıllara gelindiğinde Tıbbi Model yaklaşımı ciddi eleştirilere maruz kalarak Sosyal Modelin temelleri atılmıştır (Taşc1, 2018, s. 143). Sosyal Model, engelliliğin, bireysel yetersizliklerden daha çok engeli bireyin içinde yaşadığı toplumun ön yargiları ve ayrımcllık temelli sosyal bariyerlerin bir ürünü olduğu ana felsefesi ile şekillenmektedir (Oliver, 2013, s. 1024). Sosyal bariyer ürünü olan bu engeller mimari noksanlıklar neticesinde oluşan mekânsal engeller olabileceği gibi sağlık, eğitim gibi vatandaşlık temelli kamusal hizmetlerde de meydana gelebilmektedir. Yalın bir biçimde ifade edilecek olursa, tekerlekli sandalye kullanıcısının yüksek kaldırımlar neticesinde eğitime erişim imkânından mahrum kalması sebebiyle işsiz kalması engelli bireyin yetersizliğinden ziyade toplumsal hizmetlerin sunulmasında engelli bireylerin ihtiyaçlarının göz ardı edilmesinden kaynaklandığı bu yaklaşımdaki odak noktadır (Kolat, 2009, s. 10). Bu bağlamda sosyal model, işlev ve yapı farklılıkların ayrıca bir dezavantaja dönüşmemesi için, bireyin bağımsızlı̆̆ ekseninde fiziksel çevrenin tasarlanmasından hizmetlere erişime değin farklılıkların gözetilmesini bir zorunluluk olarak öngörmektedir.

\section{İnsan Haklarn Modeli}

İnsan Hakları Modeli; literatürde Hak Temelli Yaklaşım olarak da adlandırılan bu yaklaşım sosyal modelin üzerine inşa edilmesi sebebiyle pek çok yazında sosyal model içerisinde sunulurken değişen paradigma çerçevesinde artık kimi yazarlar tarafından sosyal modelden ayrı bir yaklaşım olarak ele alınmaktadır (Kolat, 2009, s. 12). Model engelli bireyin yetersizlikleri yerine engellere veya farklılıklara bakılmaksızın tüm insanlar için vazgeçilmez olan eşitlik üzerine odaklanmaktadır. Modele göre engelliliğin bizzat kendisi sosyal bir yapı olup bu nedenle çevresel engeller, kuramsal yapılar ve diğerlerinin tutumlarının değiştirilmesi gerekir (Kanter, 2003, s. 3). Bu kapsamda engelli birey, muhtaçlık zemininde yardım edilmesi gereken bir birey değil tam aksine hak sahibi olmasının yanı sıra korunması ve geliştirilmesi gereken aksi takdirde hakkı ihlal edilmiş hukukun öznesi bir birey olarak ifade edilmektedir (Kolat, 2009, s. 13). Öyle ki engelli bireyin salt insan olması sebebiyle 
diğerleri gibi temel hak ve hürriyetlere kendiliğinden sahip olmakta ve bu hakların kullanımı için uygun zeminin hazırlanması gerekmektedir. Diğer yandan bu hususun aksine geliştirilen her tutum engeli bireyler açısından birer hak ihlaline bürünmektedir. Ancak belirtmek gerekir ki engelli haklarının ortaya konması bakımından ulusal bazda birçok düzenlemenin yapılamayışı ve/veya yapılan pek çok düzenlemenin pasif nitelikte kalması sebebiyle uluslararası nitelikteki düzenlemeler bu husussa öncülük etmektedir. Nitekim Birleşmiş Miletler tarafından ortaya konan evrensel nitelikteki düzenlemeler engelliliğin evrensel bir mesele olduğunu gözler önüne sermekte ve bu konuda hukuksal gelişmeyi dinamikleştiren bir yapı sergilemektedir. Özelikle dünyanın birçok ülkesi gibi Türkiye tarafından da onaylanan Engelli Haklarına İlişkin Sözleşme (Resmî Gazete, 14.07.2009, sayı 27288) bu anlamda İnsan Hakları Modelini somutlaştıran, 21. yüzyılın ilk İnsan Hakları sözleşmesidir. Öyle ki sözleşmenin amacının ifade edildiği birinci maddesinde; "engellilerin tüm insan hak ve temel özgürlüklerinden tam ve eşit şekilde yararlanmasını teşvik ve temin etmek ve insanlık onurlarına saygıyı güçlendirmektir" şeklinde hak ve temel özgürlüklere tam ve eşitlik temasında vurgu yapılmaktadır. Sözleşmenin devam maddelerinde ise doktrinde kişisel, siyasal ve sosyal haklar olarak da dile getirilen hakların tasarlanmasının, ifa edilmesinin ve gerçekleştirilmesinin yeni ve açık bir dile sunulmasının yanı sıra taraf ülkelere engelli haklarının geliştirilmesi ve korunması bakımından pek çok sorumluluğu da beraberinde getirmektedir (Ektaş, 2017, s. 119). Bu kapsamda temel hak ve hürriyetlerin diğerleri gibi engelli bireyler tarafından da tam ve eşitlik ekseninde kullanılması açısından İnsan Hakları Modeli'nin “Engellilerin Haklarına İlişkin Sözleşme" ile işlerlik kazandığını ve sosyal modelden ayrışarak engelliler için ayrı bir zemin oluşturduğunu söylemek yanlış olmayacaktır.

\section{Engelli Haklarının Gelişimi Bağlamında Engelli Yaygınlığı}

Engellilere yönelik politika ve programların tasarlanması, uygulanması ve etkinliği açısından engelli yaygınlığının ölçülmesi son derece önemlidir. Ancak karmaşık ve olgusal düzlemi epey geniş olan engellilik meselesinin yaygınlığının ölçülmesinde de birçok zorluklar bulunmaktadır. Nitekim engellilik kavramının nasıl algılandığı, yetersizlik yaklaşımının mı yoksa işlevsellik 
güçlükleri yaklaşımının tercih edileceği ya da sosyal bariyerlere odaklanılmasının mı ön plana çıtığı, yaygınlık ölçülmesindeki soru, tip ve tasarımları gibi pek çok hususta ayrışmalar bulunması engellilik yaygınlığının ölçülmesinde farklılıkların ortaya çımasına neden olmaktadır (WHO, 2011, s. 27).

Engelli yaygınlı̆̆ını ölçülmesindeki farklılıkları gidererek ülkeler arası karşılaştırabilir veri toplamak amaciyla 2002-2004 yıllarında 59 ülke bazında ağırlıklı veri seti oluşturulan "Dünya Sağlık Araştırması" adı altında bir çalışma yapılmıştır. Bu araştırmanın sonuçlarına göre engellilik yaygınlı̆ı̆ın ortalama oranı; 18 yaş ve üstü nüfusta $\% 15,6$, yüksek gelirli ülkelerde $\% 11,8$ ve düşük gelirli ülkelerde ise $\% 18$ olarak belirlenmiştir. Bu sonuçlar 15 yaş ve üstünü kapsayacak şekilde genişletildiğinde ise 2004 yılı tahmini 6,4 milyar olan dünya nüfusunda 720 milyon bireyin işlev güçlügü yaşadığ 1 tahmin edilmektedir. (Dünya Engellilik Raporu, 2011, s. 23-28). Engellilik yaygınl1ğının ölçümü için yapılan bir diğer çalı̧̧ma ise "Küresel Hastalık Yükü Araştırması"'dır. Araştırma sonuçlarına göre dünya nüfusunun \%15,3'ünün orta düzeyde, \%2,9'nun ise ağır engelli olduğu belirlenmiştir. Bu hesaplamalar 14 yaş ve altı için $\% 5,1$ ve $\% 0,7,15$ yaş ve üstü için $\% 19,4$ ve $\% 3,8$ olarak belirlenmiştir (Dünya Engellilik Raporu, 2011, s. 30-31). Günümüzde ise dünyada 1 milyardan fazla insanın engelli olduğu ve 2050 yılında ise bu sayının 2 milyarı bulacağı tahmin edilmektedir (WHO, 2011).

Türkiye'de engellilik yaygınlığ 1 ile ilgili en kapsamlı araştırmalardan biri olarak telaffuz edilen ve hâlihazırda birçok güncel çalışmada kendisine yer bulan çalışma "Türkiye Özürlüler Araştırması"'dır. Araştırma, engellilik yaygınlığını, engellilerin sosyo-ekonomik yapısını sorunlarını ve beklentileri konusundaki bilgi ve veri eksikliğini gidermek amaciyla Devlet İstatistik Enstitüsü ve Özürlüler İdaresi Başkanlığı'nın iş birliği ile 2002 yılında gerçekleştirilmiştir. Araştırmanın sonuçlarına göre engelli nüfusun toplam nüfus içindeki oran $\% 12,29$ olarak tespit edilmiş olup bu oran erkelerde \%11, kadınlarda ise \%13,45 olarak belirlenmiştir. Araştırma sonuçları bölgelere göre incelendiğinde ortopedik, görme, işitme, dil ve konuşma ile zihinsel engellilik yaygınlığının en fazla olduğu bölge \%3,22 oranı ile Karadeniz Bölgesi olduğu en az olduğu bölgenin ise Marmara Bölgesi olduğu tespit edilmiştir. Bölge ayrımı süreğen hastalık ayrımı altında incelendiğinde ise süreğen hastalıklar açısından en yüksek orana sahip olan bölgenin \%10,90 ile Marmara Bölgesi olduğu en düşük orana sahip bölgenin ise \%7,18 ile Güneydoğu Anadolu Bölgesi olduğu tespit edilmiştir (Türkiye Özürlüler Araştırması, 2002, s. 4-6). 
Türkiye'de engellilik yaygınlığına ilişkin başka bir araştırma ise 2011 yılında Nüfus ve Konut Araştırması ile gerçekleştirilmiştir. Araştırma her ne kadar TÜIKK tarafından gerçekleştirilmiş olsa da engelliliğe ilişkin soruların hazırlanması "Washington Grup" önerileri temel alınarak Dünya Sağlık Örgütü tarafından geliştirilen "İşlevsellik, Engellilik ve Sağlığın Uluslararası S1nuflandırılması" ile de uyumlu olacak şekilde Engelli ve Yaşlı Hizmetleri Genel Müdürlüğü tarafından gerçekleştirilmiştir. Araştırmada engellilik; görme, duyma, konuşma, yaşıtlarına göre öğrenme, hareket güçüğü gibi fonksiyonlardaki sınırlılıklara odaklanılarak gerçekleştirilmiş olup bahsi geçen alanlarda zorluk çektiğini dile getiren bireyler en az bir engeli olan nüfus kapsamına alınmıştır. Araştırma sonuçlarına göre 3 yaş ve üstü en az bir engeli olan nüfusun genel nüfusa oranı $\% 6,9$ iken (4.876.000 kişi), bu oran erkeklerde ve kadınlarda sırasıyla \%5,9 ve \%7,9 olarak belirlenmiştir (Engelli ve Yaşlı İstatistik Bülteni, 2020, s. 3). Engel grubu ve cinsiyet ayrımına ilişkin araştırma sonuçları Tablo 1'de sunulmuştur.

Tablo 1. Genel nüfus içinde engel grubu ve cinsiyete göre engelli nüfus (2011 yıll)

\begin{tabular}{|c|c|c|c|c|}
\hline Engel Grubu & $\begin{array}{l}\text { Toplam } \\
\text { Nüfus Oranı }\end{array}$ & $\begin{array}{l}\text { Erkek } \\
\text { Nüfus Oranı }\end{array}$ & $\begin{array}{l}\text { Kadın } \\
\text { Nüfus Oranı }\end{array}$ & $\begin{array}{l}\text { Toplam Engelli } \\
\text { Kişi Sayısı }\end{array}$ \\
\hline Görmede Zorluk Yaşayanlar & 1,4 & 1,3 & 1,5 & 1.039 .000 \\
\hline İşitmede Zorluk Yaşayanlar & 1,1 & 1,1 & 1,2 & 836.000 \\
\hline Konuşmada Zorluk Yaşayanlar & 0,7 & 0,8 & 0,6 & 507.000 \\
\hline $\begin{array}{l}\text { Yürümede, merdiven } \\
\text { çıkmada/inmede zorluk yaşayanlar }\end{array}$ & 3,3 & 2,4 & 4,1 & 2.313 .000 \\
\hline $\begin{array}{l}\text { Bir şeyler taşımada/tutmada } \\
\text { zorluk yaşayanlar }\end{array}$ & 4,1 & 3,2 & 5,1 & 2.923 .000 \\
\hline $\begin{array}{l}\text { Yaşıtlarına göre öğrenmede/basit } \\
\text { dört işlem yapmada/hatırlamada } \\
\text { dikkatini toplamada } \\
\text { zorluk yaşayanlar }\end{array}$ & 2,0 & 1,6 & 2,4 & 1.412 .000 \\
\hline
\end{tabular}

(AÇSHB, Engeli ve Yaşlı İstatistik Bülteni, Ağustos 2020).

Tablo 1 yakından incelendiğinde genel nüfus içinde en fazla engellilik yaygınlığının \%4,1 oranla" bir şeyler taşıma/tutmada zorluk yaşayanlar" grubunda olduğu görülmekte olup bu oranı \%3,3 ile "yürümede, merdiven inme/çıkmada zorluk yaşayanlar" grubu izlemektedir. Tablo cinsiyet ayrımı dâhilinde incelendiğinde konuşmada zorluk çekme haricinde diğer tüm alanlarda kadınlarda erkeklere kıyasla engellilik yaygınlığının daha fazla olduğu görülmektedir. Hem dünya genelinde hem de Türkiye' deki sonuçlara göre engellilik yayginlığı giderek artmakta ve engelli nüfusu genel nüfusta 
ciddi bir oranı temsil etmektedir. Görüldüğü üzere hem engelliler hem de engelliliğin kendisi, insanlığın ve sosyal dokunun ayrılmaz bir parçası halindedir. Bu nedenle engellilere yönelik doğru ve etkin politikaların geliştirilmesi bu açıdan elzem bir nitelik taşımaktadır.

Engellilere yönelik sosyal politikaların gelişimi 20. asrın başlarına dayanmaktadır. I. Dünya Savaşı'na değin engellilerin engel türlerine göre eğitim alabilmelerini sağlayabilecek şekilde eğitim tekniklerinin geliştirilmesi bu alandaki sosyal politikaların başlangıcı sayılabilir. I. Dünya Savaşı sonrası ise mesleki ve tıbbi rehabilitasyon önem kazanmaya başlamış olup II. Dünya Savaşı sonrasına değin engellileri işgücü piyasalarında entegre edebilme çabaları devam etmiştir (Seyyar, 2015, s. 95). Engelli haklarına yönelik esas gelişim ise ancak 1970'li yıllarda yaşanmıştır. 1970'li yıllarda başta ABD'de olmak üzere Avrupa ülkelerinin birçoğunda engellilere yönelik hukuki düzenlemelerin yapılması, engelli hakları hareketlilerinin de etkisiyle 1980'li yıllardan itibaren tam katılım, eşitlik ve ayrımcılıkla mücadele pek çok ulusal ve uluslararası düzenlemenin konusu haline gelmiştir (Orhan, 2015, s. 81). Bu minvaldeki düzenlemeler içerisinde yer alan EHİS hiç kuşkusuz bu düzenlemelerin en önemlilerinden biri olup hem insan hakları hem de engellilik meselesi açısından bir dönüm niteliği taşımaktadır. Nitekim EHİ'in Tibbi Model yerine toplumsal yaşama katılımı ve bağımsız yaşamı esas alan Sosyal Model üzerine inşa edilmiş olması, sözleşmenin özel standartlara ve ölçütlere dayalı olarak düzenlenmemesi ve özelikle sözleşmenin taslak metninin hazırlanmasinda World Blind Union, World Federation of the Deaf and World Federation for Mental Health gibi Hükümet Dışı Örgütler içerisinde 400'den fazla engelli örgütlerine de aktif sorumluluk verilmiş olması engellilerin sorunlarını çözüm odağında ele almasını sağlayarak EHİS'i diğer insan hakları sözleşmelerinden farklı kılmaktadır (Ektaş, 2017, s. 35-7, 111-3). Bu bağlamda bir dönüm noktası özelliği taşıyan EHIS, günümüzde de engelli haklarının gelişmesi açısından da önemli bir zemin niteliği taşımaktadır.

Günümüzde engelli haklarının ve sosyal politikaların gelişimi ile engellilerin sosyal hayata entegre olmasını sağlamak için engellilerin erken safhalarda tıbbi tedavi ve rehabilitasyondan yararlandırılmalarını sağlamak, özel eğitim gereksinimlerini karşılamak, işgücü niteliği taşıyan engelliler açısından mesleki rehabilitasyonu sağlamak, sosyal yardım ve bakım hizmetlerini geliştirmek öncelikli hedefler arasında sıralanmaktadır. Belirtmek gerekir ki 
engellilerin sorunlarının görmezden gelinmesi bir insan hakkı meselesi olduğu gibi aynı zamanda hiç kuşkusuz sosyal siyasettin ilkesi olan sosyal barış ve sosyal adalette aykırı bir durum olarak da görülmektedir. Bu bağlamda özel ve kamusal hakların tüm vatandaşlara eşitlik temasında verilmesi esas iken dezavantajlı gruplar içerisinde yer alan engelli bireylerin de bu haklardan fırsat eşitliği ilkesine göre yararlandırılmaları elzem bir nitelik taşımaktadır. Ne var ki engellilere yönelik sunulması gereken etkin bir fırsat eşitliğinin sağlanması ancak karar alma sürecinde engellilerinde bulunması ile mümkün k1lınabilecektir (Seyyar, 2015, s. 96-101). Belirtmek gerekir ki engellilerin de karar alma süreçlerine katılmalarının önündeki bariyerlerin kald1rılması, EHİS'e taraf devletlere getirilen yükümlülükler arasındadır. Sözleşmenin "Siyasal ve Toplumsal Yaşama Katılım Hakkı" kenar başlıklı 29. maddesi bu yönde hükümler içermektedir. 29. madde ile taraf devletlere, engellilerin diğer bireylerle eşit koşularda seçme ve seçilme hakları dâhil olmak üzere siyasi ve kamusal yaşama etkin şekilde katılımlarını sağlamak, seçim usüllerinin, materyallerinin uygun, erişilebilir ve anlaşılabilir olmasının yanında seçim mekânlarının uygunluğu ve ulaşabilirliğinin sağlanması, engellilerin hiçbir baskıya uğramadan gizli oy kullanmalarının, aday olma, etkili bir mevkide görev alma haklarının sağlanması, ülkenin kamusal ve siyasi yaşamı ile ilgili sivil toplum kuruluşları, dernekler ve siyasi partilerin etkinliklerine ve yönetimine katılım gibi hakların sağlanması yönünde çeşitli yükümlülükler getirilmektedir (EHIS, m. 29).

$\mathrm{Bu}$ çerçevede engellilerin toplumsal hayata dâhil olabilmesi ancak hak düzleminde etkinleştirilen etkin ve doğru sosyal politikalarla hayatta geçirilebileceğini bunun için ise engellilerin de karar alma sürecinde etkinliğinin artırılması gerekliliğini söylemek yanlış olmayacaktır. Nitekim engelli hareketlerinin en önemli sloganlarından biri olan "Biz olmadan bizler hakkında asla" (Nothing about us without us) söylemi engellilerinde karar alma sürecinde olması gerektiği düşüncesi ile uyumlu bir şekilde örtüşmektedir. Bu noktadan hareketle engellilerin siyasi temsil sorunlarının ele alınması yerinde olacaktır. 


\section{Temsil, Aktif Statü Hakkı ve Engelliler}

Günümüz manasında temsil, 12. yüzyılla birlikte sadece bir kavram olarak değil aynı zamanda bir kurum olarak da ortaya çıkmıştır. ${ }^{3}$ Öncesinde, doğrudan demokrasinin hâkim olduğu Antik Yunan'da böyle kavrama doğal olarak rastlanmamaktadır. Kavramın etimolojik kökeni Romalılardan kalan "repraesentare" kavramında türemiştir. Fakat bu kavram günümüz anlaminda değil "somutlaştırmak" manasında, siyasal bir olgudan ziyade sanatsal birtakım anlamlar içermekteydi. Ardından kavram dönemin ruhuna uygun bir biçimde oldukça dini motifler taşımaktaydı. Skolastik ve Papist düşüncenin Orta Avrupa'da yoğun bir etkisinin olduğu ve Katolik Kilisesi'nin idari genişleme bağlamında önemli ilerleme kaydettiği bu zamanlarda, Papa Clement V, Viyana Konseyi'ne delege göndermek suretiyle 1311 yılında "temsil" kavramına günümüzde kullanıldığı biçimine yakın bir şekil vermiş oldu. Bahsi geçen yüzyıl boyunca temsil kavramı henüz dini etkilerden kurtulamamış ve siyasi bir nitelik kazanamamıştır. Fakat gerek kanonist hukukçular ${ }^{4}$ gerekse sivil hukukçular arasında kavram dini çağrışımlardan kurtarılıp modern içeriğine kavuşturulmuştur (Örs, 2006, s. 3-4).

Siyasette temsil ise kimi kişilerin bu hakkı kendisine devredenler adına hareket etmesi anlamına gelmektedir. Bir monark, bir diplomat veya bir bayrak bu bağlamda temsil işini yerine getirmiş olurlar (Miller, 1995, s. 358-9). Roma İmparatorluğu' nun dağılmasının ardından ortaya çıkan otorite boşluğunun teolojik bir iktidar tarafından doldurulması ve siyasal örgütlenme biçimlerinde belirleyici rol oynayan Skolastik ve Papist düşünce döneminde temsil kavramı siyasal açıdan yalnızca feodal beylerin kullanımına özgü bir hal almıştı (Sayınta, https://ayrintidergi.com.tr/siyasal-temsil-uzerine-temelbelirlemeler/ 15/12/2020). Feodal düzenin, Bodin'in egemenlik anlayışıyla şekillenen ve teorik altyapısına Machiavelli'nin katkı sunduğu mutlak monarşi

\footnotetext{
${ }^{3}$ Katolik Kilisesi’nin tesir alanının genişlemeye başlamasıly birlikte, coğrafi alanlar arasındaki birliğin ve eşitliğin sağlanabilmesi bir takım yeni kavramlara ve kurumlara ihtiyaç duyulmuştu. Özellikle hukuk alanında ihtiyaç duyulan ve Roma Hukuku'na ait iki kavramın tekrar gündeme gelişi; kolektivite anlamında "universitas" ve bir başkasını temsil eden birey manasında "procurator" terimlerinin öne çıkmasına ön ayak olmuştur (Örs, 2006, s. 3).

4 "Kanonistler, Kilise hukukunun kaynaklarını belirlerken ilahi kaynaklar ve beşerî kaynaklar olmak üzere ikili bir sınıflandırma yapmış, Hz. Musa ve Isa'ya vahyedilen ve Kitabı Mukaddes'te nakledilen hukuk kuralları ile Doğal (Tabii) hukuk kurallarını "ilahi hukuk" olarak tanımlamışlardır. Bunun dışında kalan ve genelde Kilise hiyerarşisinden müteşekkil olan hukuk kaynaklarını ise beşerî olarak nitelemişlerdir" (Bahçekapill, 2009, s. 52).
} 
tarafından sarsılması, temsil bahsini tekrar gündeme taşımıştır. İnsanların bir arada yaşama ihtiyacı neticesinde birtakım gereksinimler ortaya çıkmıştır. Bu gereksinimlerin en önemlilerinden biri kimin, nasıl yöneteceği sorusuna verilecek yanttır. Bodin' in egemenliği mutlak, bölünemez ve devredilemez bir niteliğe sahipti. Bu biçim, öncesinde, cumhuriyetçi eğilimlerle neticelenecek olan Machiavelli'nin fikirlerinde ardinda da Hobbes'un Leviathan'ında karşımıza çıkmaktadır. Egemenin sahip olduğu bu teorik donanım toplumsal/siyasal hayatta tahayyül edildiği biçimde karşılık bulmamıştır. Zira yönetme işi tek taraflı olmamış, çeşitli sınıflar ile yöneticilerle sürekli bir karşı karşıya gelme durumunda kalmışlardır. Bu karşılaşmalar zamanla mutlak monarşinin çeperlerini zayıflatmış, kuvvetler ayrılığı düşüncesinin ortaya çıkmasına ve temsil biçimlerini kullanarak yetkilerin dağıtılmasına neden olmuştur (Öztürk, 2020).

Tarihsel gelişim seyri yukarıda bahsi geçen toplumsal, ekonomik ve siyasal pek çok değişim neticesinde temsilin gerektirdiği işlevleri yerine getirebilmek adına yeni kurumsal yapıları ortaya çıkmıştır. Bu yapıların başında ise mutlak monarşilerden hukuk devletine geçişi sembolize eden parlamentolar gelmektedir. Bu bakış açısının yanı sıra çağdaş manada temsil, yasama organı diğer bir ifadeyle temsili hükümet bağlamında karakterize edilir (Örs, 2006). Nüfusun yoğun olmadığı dönemlerde karar alma süreçlerine doğrudan katılım söz konusuydu fakat burada dikkat edilmesi gereken husus bu doğrudan katılımın halkın tamamını kapsamadığı aksine cinsiyet, yaş, ırk, sosyal ve ekonomik konum gibi temel belirleyicilere göre hareket edildiğidir. Ardından gelen tartışmalar ise öncelikle artan nüfus neticesinde artık doğrudan katılımın mümkün olmadığı ve temsilin belirli kurallarla işlerlik kazandırılması üzerine yoğunlaşmıştır (Dahl, 2019, s. 27-30). Antik Yunan, Roma İmparatorluğu, Karanlık Orta Çağ ve Mutlak Monarşi'lerin arından tarihsel, siyasal, ekonomik, toplumsal ve bilimsel birikimin neticesinde kimi yerlerde devrimsel kimi coğrafyalarda ise evrimsel bir sürecinden arından modern devlet/hukuk devleti/ulus devlet olarak nitelendirilen yeni bir siyasal örgütlenme biçimi ortaya çıkmıştır. Bu örgütlenme biçimini diğerlerinden ayıran önemli nitelikler; birey ve devletin hukuk kurallarına tabi olması, bireyin devlet yönetimine katılması ve oldukça önemli diğer bir fark ise birey, "yurttaş” olarak tanımlanmaya başlanmıştır. Önceki zamanlarda yönetici sınıf belirli geleneklere bağlı kalmak koşuluyla ve fakat yine de denetim mekanizması bulunmadan yönetim işlevini gerçekleştiriyordu. Bununla birlikte yanlarında yine 
aristokratlar, askerlerden ya da başka imtiyazlı sınıflardan oluşan birer danışma kurulu niteliğinde yapılar mevcut olsa da nihai karar yine tek kişideydi. Modern devlet bu yönetim biçimlerini ortadan kaldırıp hukuk ve temsil esasına dayanan bir örgütlenme biçimi şekilde ortaya çıkmıştır. Bunlara ek olarak modern devlet bireyleri; cinsiyet, ırk, sosyal köken, kan bağı̆, ekonomik güç gibi çeşitli sınıflandırmalara tabi tutmadan her bireyi eşit kabul ederek, onları yurttaş olarak tanımladı ve birtakım haklar bahşetti.

Daha geniş anlamda temel hak ve hürriyetler şeklinde tanımlanabilecek bu haklar çok daha sonra Georg Jellinek tarafından bir sınıflandırmaya tabi tutulacak ve literatürde temel bir ayrım olarak üç başlık altında incelenecektir. Bunlar; Negatif Statü Hakkı, Pozitif Statü Hakkı ve Aktif Statü Hakkı'dır. Negatif statü hakları, kişinin devlet tarafindan dokunulamayacak, özel alanını belirleyen hak ve hürriyetlerdir. Bu haklar kişinin insan olması nedeniyle sahip olduğu, devletin ona özgülemediği ve asıl olarak kişiyi devlete karşı koruyan niteliğiyle "koruyucu haklar" olarak da tanımlanmaktadır. Kişi güvenliği, düşünce hürriyeti, din hürriyeti, mülkiyet hakkı ve konut dokunulmazlığı negatif statü haklarına örnek gösterilebilir (Gözler, 2019, s. 140). Pozitif statü hakkı ise kişilerin devletten talep etme hakkı olarak tanımlanabilir. Sağlık hizmeti, sosyal yardım gibi konularda devletten talepte bulunulan haklardır. İsteme hakkı ve sosyal haklar olarak nitelendirilmektedir (Gözbüyük, 1998, s. 167; Gözler, 2019, s. 141). Sınıflandırmanın son ayağını ise aktif statü hakları oluşturmaktadır. Bu haklar kişinin devlet yönetimine katılmasını sağlayan haklardır bu bağlamda katılma hakları olarak da karşımıza çıkar (Kapani, 1981, s. 6). Halkın yönetime katılma biçimlerine ilişkin olan bu hak türü seçme ve seçilme hakkı, siyasi parti kurma hakkı gibi siyasal hakların yanı sıra dilekçe hakkı ve kamu hizmetlerine girme hakkı gibi temel hakları da kapsamaktadır.

Jellinek'in sınıflandırması, hukuk ile ilgili diğer sınıflandırmalar da olduğu üzere, ağırlıklı olarak eşitlik temeline oturtulmuştur. Bu eşitlik, biraz önce bahsi geçen cinsiyet, ırk, sosyal köken, kan bağı ve ekonomik güç gibi unsurların yurttaşların devletin her birine eşit mesafede durmasını etkilemediği varsayımını içermektedir. Bu tartışmalı alanın çalışmanın sınırlarını aşacağı endişesiyle başka bir bahiste ele alınması ve bahsi geçen varsayımın doğruluğu en azından bir anlık kabul edilerek çalışmaya devam edilecektir. Devletin her yurttaşına eşit mesafede durması bir yandan eşitliğe yapılan vurgunun önemli simgeleri arasında yer almaktadır. Fakat diğer yandan toplumu 
meydana getiren bireyler homojen olmadığı gibi göz ardı edilemeyecek kadar dezavantajlı gruplar bulunmaktadır (TÜíK'in 2011 yılındaki araştırmasina göre, Türkiye' de 9 milyonun üzerinde engelli birey bulunmaktadır). Modern devletler dezavantajlı grupların toplumsal eşitliğini sağlamak adına anayasal tedbirler almakta ve bu tedbirlerin hayata geçirilmesi adına "pozitif ayrımcılığa" eğilim göstermektedirler. Örneğin, Türkiye Cumhuriyeti Anayasası'nın 10. Maddesinde; "Herkes, dil, ırk, renk, cinsiyet, siyasi düşünce, felsefi inanç, din, mezhep ve benzeri sebeplerle ayırım gözetilmeksizin kanun önünde eşittir. Kadınlar ve erkekler eşit haklara sahiptir. Devlet, bu eşitliğin yaşama geçmesini sağlamakla yükümlüdür. Bu maksatla alınacak tedbirler eşitlik ilkesine aykırı olarak yorumlanamaz. Çocuklar, yaşlılar, özürlüler, harp ve vazife şehitlerinin dul ve yetimleri ile malul ve gaziler için alınacak tedbirler eşitlik ilkesine aykırı olamaz. Hiçbir kişiye, aileye, zümreye veya sınıfa imtiyaz tanınamaz. Devlet organları ve idare makamları bütün işlemlerinde kanun önünde eşitlik ilkesine uygun olarak hareket etmek zorundadırlar." bu tedbirlerin toplumsal eşitliği sağlamak adına alındığı vurgulanmaktadır. Pozitif ayrımcllık, toplumsal alanda diğer bireylerle eşit durumda olmayan ve üretilen politikalar neticesinde ayrımcilığa uğrayan ve bundan dolayı çeşitli haklardan ve hizmetlerden mahrum kalan ya da bu hizmetlere erişimde zorluk yaşayan grupların lehine geliştirilen politika, yöntem ve uygulamaları karşılayan genel bir kavramdır (Akbaş ve Şen, 2013, s. 167). Kavram, ilk olarak Amerika Birleşik Devletleri'nde Nathan Glazer tarafından "olumlu eylem" kavramsallaştırmasının karşılığı olarak kullanılmıştır (Dotcheva, 2009, s. 97). Pozitif ayrımcilik bir yandan dezavantajl grupların toplumsal entegrasyonu için önemli bir kavram olarak karşımıza çıkarken diğer yandan muhtevası gereği oldukça politik bir değere sahiptir. Schnapper pozitif ayrımcılık ile ilgili olarak onun "toplumsal yaşamın çeşitli kademelerinde farklı grupların eşit temsil edilmesi" yönüne vurgu yaparken "adil paylaşım politikaları ya da kota siyaseti" biçiminin de politikliğini vurgulamaktadır (Schnapper, 2005, s. 355).

Schnapper'in yapmış olduğu vurgu farklı bir bakış açısıyla C. Mouffe'da da karşımıza çıkmaktadır. Mouffe, bütün toplumsal nesnelliklerin eninde sonunda politik olduğu dile getirmektedir (Mouffe, 2001, s. 32). Toplumsal olanın politikliği, çalışmanın temel önermesi olan engellilerin toplumsal yerini belirleme konusunda ortaya atılan "insan hakları modeli" ile Jellinek' in "aktif 
statü haklarını" ilişkilendirilmesini anlamlandırmada önemli bir zemin sağlamaktadır. İnsan hakları modeline göre engellilik sosyal bir yapı olduğundan dolayı çevresel engeller, kuramsal yapılar ve diğerlerinin tutumlarının değiştirilmesi gerekir (Kanter, 2003, s. 3). Bu bağlamda daha önce de değinildiği üzere engelli birey, muhtaç olarak tanımlanıp yardım edilmesi gereken bir konumda değil tam tersine sahip olduğu hakların yanı sıra "pozitif ayrımcılıkla" bu hakların korunması ve geliştirilmesi gereken, bu yapılmadığı zaman hakları ihlal edilmiş hukukun öznesi bir birey olarak görülmektedir (Kolat, 2009, s. 13). Öyle ki engelli bireyin salt insan olması sebebiyle diğerleri gibi temel hak ve hürriyetlere kendiliğinden sahip olmakta ve bu hakların kullanımı için uygun zeminin hazırlanması gerekmektedir. Bu anlayış, kişinin salt insan olmasından kaynaklı sahip olması gereken haklar bağlamında "negatif statü haklarına" oldukça yaklaşmaktadır. Diğer yandan engelli bireylerin toplumsal entegrasyonu sürecinde engelli olmaları hasebiyle sahip oldukları/olması gereken hakların yanı sıra taleplerini de dile getirebilecekleri daha geniş bir etki alanına sahip birtakım araçlara ihtiyaç duydukları görülmektedir. Bu bağlam ise siyasal katılım haklarının etkin kullanımını gerekli hale getirmektedir. Gerek siyasal hakların etkin kullanılması gerekse de toplumsal olanın doğası gereği politik olmasından kaynaklı; engellilerin toplumsal yerini açıklamada kullanılan "insan hakları modeli" Jellinek' in "aktif statü haklarını" da içermesi gerekmektedir. Siyasal hakların kullanılmasında ise en temel araç siyasal partilerdir. Siyasal partiler bu açıdan yaklaşıldığında bir köprü vazifesindedir.

\section{Engellilerin Siyasal Temsiline İlişkin Bir Örnek: Türkiye Özürlüleri ile Mutludur Partisi}

Siyasi partiler, ortaya çıtı̆̆ ilk zamanlarda, baskı grupları ve toplumsal hareketlerden farklı olarak hükümet iktidarını ele geçirmek ve kullanmak, çeşitli gruplardan oluşan üyeleriyle örgütlenmiş organik bir yapı kurmak, makro ölçekli konulara odaklanmayı kendisine amaç edinmiş ve genel bir ideolojik kimliğe sahip bir bütünlük olarak nitelendirilebilir (Heywood, 2015, s. 303-4). Diğer bir ifadeyle; "bir parti, tek bir topluluk değil, birçok toplulukların yarattığı bir bütün, ülke içinde dağılmış ve koordinatör kurumlar vasıtasıyla birbirlerine bağlanmış küçük grupların (ocaklar, komiteler, yöresel demekler, vb.) meydana getirdiği bir birliktir" (Duverger, 1974, s. 51-2). Siyasi 
partiler ve sahip oldukları anlam ve içerik, ortaya çıktıkları zamanlardan günümüze dek pek çok açıdan değişim, farklılaşma ve gelişim göstermiştir. Bu süreç beraberinde oldukça çeşitli parti tipolojilerini de beraberinde getirmiştir. Çekirdek ve kitle partileri, temsilci ve birleştirici partiler, anayasal ve devrimci partiler, sağ-kanat ve sol-kanat partiler en yaygin tipolojiler olarak karşımıza çıkmaktadır. Sınıflandırmaların temel ayrıştığı nokta odaklandıkları, alanlardır. Bu noktalar aynı zamanda partilerin işlevleriyle de paralellik sunmaktadır. Başta temsil olmak üzere hedef belirleme, menfaatleri ortaya koyma ve açılama, sosyalleşme ve sosyal hareketlilik ve nihayetinde hükümetin organizasyonu gibi işlevleri olan siyasal partiler bu geniş ölçekli siyasa üretme çabalarının yanı sıra aktüel manada farklı işlevleri de bünyesine dahil etmeye çalışmaktadır. Büyük partilerin aksine, küçük partilerin iktidarı ele geçirme arzusundan ziyade belirli bir taban kazanma güdüsü öte yandan yine küçük partilerin tüm seçmen kitlesine hitap etmek yerine tek bir konuya odaklanmaları da güncel olarak karşımıza çıkan yeni unsurlardır (Heywood, 2007, s. 356-8).

Bahsi geçtiği üzere siyasal partiler; sosyalleşme ve sosyal hareketlilik, belirli bir konuya odaklanma ve mikro ölçekli sorunlar özelinde bir araya getirme işlevlerine sahiptir. Bu zemin öncelikle engelli bireylerin toplumsal entegrasyonunda siyasal partileri bir araç olarak kullanarak sosyalleşme ve sosyal hareketliliği sağlayabilmesine imkân tanımaktadır. Engellilerin toplumsal yerini anlamlandırmada kullandığımız "insan hakları modeli" bağlamında engellileri "temsil" eden bir siyasal partinin olması gerek onların toplumsal entegrasyonunda gerekse sorunlarını ifade etmede önemli görülmektedir ${ }^{5}$. Bu iki kavram (engellilerin toplumsal entegrasyonunda insan hakları modeli ile siyasal partiler) arasındaki işlevsel kavram ise, daha önce değindiğimiz, siyasal katılım hakkının kapsayan Jellinek'in “aktif statü hakkı"dır. Bu açıdan bakıldığında çalışmada önerdiğimiz Jellinek'in aktif statü haklarının, engellilerin toplumsal yerini açıklamada kullanılan insan haklarına modeline entegrasyonu; sosyalleşme ve sosyal hareketlilik, belirli bir konuya odaklanma ve

\footnotetext{
${ }^{5}$ Ülkemiz özelinde yapılan bir araştırmada, katılan engelli vatandaşların \%98'i siyaset kurumunun engelli bireylerin siyasal yaşama katılmalarını önemsemediklerini düşünmektedirler. Siyasi parti yöneticilerinin engelli bireylerin karşılaştıkları sorunların çözümüyle ilgilenmediklerinin düşünenlerin oranı yine \%98 gibi oldukça yüksek seyretmektedir. Araştırmada karşımıza çıkan diğer önemli husus ise engelli bireylerin \%97'si siyasal hataya istedikleri düzeyde katılmadıklarını ve bunların \%95,1'i siyasal hayata katılımda toplumdan yeterli desteği alamadıklarını düşünmektedirler (Karataş ve Oran, 2007, s. 14).
} 
mikro ölçekli sorunlar özelinde bir araya getirme işlevlerini gerçekleştirmek üzere siyasi bir partinin kurulmasıyla işlerlik kazanacaktır.

Klasik parti tipolojilerinden farklı olarak kimi küçük partiler dar anlamda bir parti çevresi oluşturmaya yönelmektedirler. Bu dar çevre toplumsal hassasiyetin arttı̆̆ alanlara odaklanmaktadır. Örneğin Amerika Birleşik Devletleri'nde 1918'de kadınların oy hakkını savunan Ulusal Kadınlar Partisi (National Woman's Party) (https://www.nationalwomansparty.org/ 10/01/2021), Türkiye'de kadın haklarını savunan ve Meclis'te erkek egemenliği eleştiren, 1972'de kurulan Türkiye Ulusal Kadınlar Partisi (https://web.archive.org/web/20160527053434/https://www.tbmm.gov.tr/kutuphane/siyasi partiler.html 10/01/2021). Doğal yaşamın korunmasına (GroenLinks partisi sol çizgide olmakla birlikte odaklandığı asıl konu "yeşil siyaset"), hayvan haklarının gündem tutulmasına (Party for the Animals (PvdD) ve irkç1lığa karşı tutum (Denk Party, kimlik politikalarına ve ırkçlık karşıtı tutum benimsemektedir) ${ }^{6}$ gibi konulara yoğunlaşabilen bu tarz küçük partilerin asıl amaçları iktidarı ele geçirmek değil mecliste yer alıp ilgili konulara dikkat çekmek, onları gündemde tutmak ve sahiplendiği konularla ilgili karar alma süreçlerinde yer edinmektir. Çalışma özelinde bakıldığında benzer bir eğilim engelli haklarının dile getirilmesi, korunması ve engellilerle ilgili karar alma süreçlerinde yer alma gibi temel kaygıları olan bir küçük parti deneyimi Türkiye'de de yaşanmıştır.

Türkiye Özürlüsü ile Mutludur Partisi, 1996 yılında Murat Dilmen tarafından kurulan bir partidir. Kendisini ideolojik olarak siyasal yelpazenin sağında veya solunda tanımlamaktan ziyade siyasi duruşu görünüm olarak merkezdedir. Partinin genel amacı engelli vatandaşların yaşam koşullarını iyileştirmek, partilerin siyasi temsil gücünün kullanarak engelli bireylerin taleplerini siyasal zeminde dile getirmek olmuştur (Türkiye Özürlüsü ile Mutludur Partisi Tüzük ve Programı; 1996). Parti, kimilerine göre "tuhaf" olarak nitelendirilse de (https://meydan.org/2014/12/21/siyasi-tarihin-en-tuhaf-partileri-ve-e-parti-ilyas-seyrek/, 20/01/2021) engelli haklarının varlı̆̆ını, korunmasını ve geliştirilmesini temel alan bir felsefeye sahip olması bakımından önemli bir girişim olarak nitelendirilmelidir. Türk siyasal hayatında uzun so-

\footnotetext{
${ }^{6}$ Bahsi geçen 3 siyasal parti Hollanda'daki temsil sisteminden örneklendirilmiştir (https://en.wikipedia.org/wiki/Politics of the Netherlands\#: :text=The\%20major\%20political\%20parties\%20are,centre\%2Dright\%20Christian\%20democratic\%20party, 10/01/2021).
} 
luklu bir parti olamayan Türkiye Özürlüsü ile Mutludur Partisi, Türkiye Büyük Millet Meclisi kayıtlarına göre sponsor bulamadığ1 ve maddi sıkıntılar yaşadığı gerekçesiyle 2003 yılının sonlarında fesih kararı almıştır (https://www.tbmm.gov.tr/kutuphane/siyasi partiler.html 20/01/2021). Diğer yandan, “Türkiye Özürlüsü İle Mutludur Partisi'nin, kurulduğu tarihten itibaren aralıksız iki dönem TBMM genel seçimlerine katılmamış olması nedeniyle 2820 sayılı Siyasi Partiler Kanunu'nun 105. maddesi uyarınca kapatılmasina karar verilmesi istemi" (https://www.resmigazete.gov.tr/eskiler/2005/02/20050208-24.htm 20/01/2021) ile Anayasa Mahkeme'sine dava açılmasını takip eden süreçte yapılan kongrede kapanma kararı almıştır. Fakat Anayasa Mahkemesi, partinin kendini feshetmesinin üzerinden 13 ay geçtikten sonra parti kapatma davasının reddine karar vermiştir. Bir siyasi parti olarak engelli haklarını savunan felsefeye sahip olan Türkiye Özürlüsü ile Mutludur Partisi'nin açtı̆̆ yolu takip eden 2007 yılında kurulan Türkiye Özürlüler Partisi ve akabinde 2012 yılında Engelsiz Türkiye Partisi ise daha sonra kendi iradeleriyle fesih kararları almıştır.

Türkiye Özürlüsü ile Mutludur Partisi bir yandan dezavantajlı bir grup olarak engelli vatandaşların haklarının korunması, taleplerinin dile getirilmesi ve kendileriyle ilgili kararlar alınırken temsilcilerinin süreçlere dahil olması adına kendini var eden bir parti olurken diğer yandan parti, partilerin işlevlerinden olan sosyal mobilizasyon ve sosyalleşme aracı niteliği bağlaminda engellilerin toplumsal entegrasyonunda önemli bir yere sahip olabilirdi. Batı'daki örneklerini kadar başarılı bir siyasal tecrübeye sahip olamayan, yine de böyle bir siyasal eğilime sahip olması ve benzer siyasi/felsefi akımlara yön göstericiliği açısından kıymetli bir yere sahiptir. Ülke nüfusunun yaklaşık \%12'si "engelli" olduğu bir toplumsal yapı, daha önce dile getirildiği üzere, engellilerin \%98'inin siyasal hayata katılımda temsile ilişkin olumsuz görüşe sahip olması, engellilerin toplumsal entegrasyonunda yaşanan sorunlar gibi unsurlar Türk siyasal hayatında "engelli haklarını" merkezine alan bir parti ihtiyacına işaret etmektedir.

\section{Tartışma ve Sonuç}

Günümüzde engellilerin toplumsal yerini anlamlandırmak ve açıklamak için kullanılan modellerden olan insan hakları modelinin bahsi geçen işlevinin 
yanı sıra engelli vatandaşların toplumsal entegrasyonunda bir başlangıç noktası olabileceği çalışmada varılan sonuçlardan ilkidir. Zira diğer modeller engelliliği ve engellileri "ötekileştiren" bir bakış açısıyla utanç verici, kusurlu ve yetersizlik gibi kavramlarla ilişkilendirerek bir anlamlandırma güdüsüyle hareket etmektedirler. Fakat insan hakları modelinde öncelikle engellilerin insan olmaları hasebiyle sahip oldukları hakları ve bunları kullanma haklarını en doğal inisiyatifleri olarak değerlendirmektedir. İnsanlık onuruyla temas eden insan hakları modeli engellilerin toplumsal yerini açıklarken, çalışmadaki ön kabullerimizden biri olan toplumsal olanın nihayetinde siyasi olduğu düşüncesinden yola çıkarak engellilerin bilhassa kendisini ilgilendiren konuları dile getirme, gündeme taşıma ve bu konular hakkındaki karar alma süreçlerine dahil edilmesini zaruri kılmaktadır. Bu bağlam çalışmada önerdiğimiz ana unsuru meydana getirmektedir: vatandaşların siyasal katılım hakların içeren Jellinek' in "aktif statü haklarını", insan hakları modeline dahil etmek. Modern zamanlarda karşımıza çıkan vatandaşların siyasal zeminde kendilerini ifade etme biçimi olarak temsili demokraside siyasal partilerin rolü yadsınamaz. Siyasal partiler ilk ortaya çıkmaya başladığı anlardan itibaren asıl amaçlarının iktidarı ele geçirmek olduğu aşikârdır. Fakat aktüel olarak küçük partiler olarak nitelendirilen partilerin ortaya çıkması, partilerin sadece iktidarı hedeflemeden kendi savunduğu değerleri politik zeminde dile getirme gibi işlevini de gündeme taşımıştır. Bu bağlamda çalışmada ulaşılan diğer sonuç engellilerin haklarını savunacak ve gündemde tutacak bir partinin oluşturulması gerek partinin bahsi geçen aktüel işlevine hizmet edecektir gerekse partilerin sosyal mobilizasyon ve sosyalleşme pratiğini dikkate alarak engelli vatandaşların toplumsal entegrasyonuna katkı sağlayacaktır. Bu yönde kurulan Türkiye Özürlüsü ile Mutludur Partisi resmi kayıtlara göre maddi yetersizliklerden kendini feshetmiştir. Türkiye Özürlüsü ile Mutludur Partisi'nin seçimlere art arda iki kere katılmamasından dolayı aleyhine açlan kapatma davası ve dava sonuçlanmadan kongre kararı neticesinde kendini feshetmesi siyasi bir küskünlük olarak yorumlanabilir. 
EXTENDED ABSTRACT

\section{An Essay on Political Representation in Social Integration of Disabled People: Turkey Happy with Disabled Party \\ *

\author{
Ersin Eraslan-Melih Coşgun \\ İstanbul University - Niğde Ömer Halisdemir University
}

It is known that disabled citizens face many different problems in the social order. The problems faced by the disabled while receiving health services, the difficulties they encounter during their education, being pushed out of the labor market when they want to work are the problems they face even in meeting the most basic needs. With the help of various organizations, especially non-governmental organizations, these problems are tried to be overcome. On the other hand, when we look at the historical process, it is seen that different groups that make up the society have come together in line with their interests over time and demanded regulations from the administrators/state/government. This context, on the other hand, leads us to the reality that all social objectivity is ultimately political, as Mouffe emphasizes. Because it is seen that the classes and groups that make up the society come together with organizational forms such as foundations, associations, unions and political parties in order to fulfill their demands and to become stronger many times. From this point of view, the main problematic of the study is; It is built on the fact that there is a lack of political representation of the disabled on the level of representation. This study proposes the integration of the right of political representation to the social rights that the disabled have but need to be developed. Today, it is an indisputable fact that the social integration of disabled citizens is mainly focused on education, health and economic problems. Without ignoring this reality, efforts to improve the problems of disabled people who are already in disadvantaged groups should be made on the basis of their negative and positive status rights. In other words, these improvement efforts are not a blessing, but a necessity. The fact that is aimed to emphasize the deficiency of the study is about the necessity of creating a more effective political representation mec- 
hanism in order to express the rights of the disabled and find a field of application. In this context, associations and foundations related to the disabled who are currently continuing their work constitute a part of the representation. However, these formations cannot be transformed into adequate and effective organizations. As a matter of fact, the current social exclusion problems of the disabled regarding unemployment, education and health services are an indicator of this situation. In this context, the aim of the study is to reveal the extent of the political representation of the disabled, which is a substantial number in society. In this context, the experience of Turkey is Happy with the Disabled Party has been included in the study, and this representation problem, which resulted in the party closure case and its subsequent dissolution, is also discussed in the study.

The purpose of this study, in the context of the social rights of people with disabilities in Turkey, political participation and political representation of the social / political life is to determine the location. The "basic approaches to disability", which has been put forward because of the efforts to explain and make sense of the place of the disabled in social life, constitute one leg of the theoretical framework of the study. However, the other leg of the theoretical part is the context in which the concepts of human rights and political representation are handled. This article proposes to articulate Jellinek's "rights to active status" to the thinking system built on human rights put forward by the basic approaches to explain disability. In addition, by establishing a nexus between the functions of political parties and the human rights model, a narrative about the importance and necessity of political representation in the social integration of the disabled is included. Based on the current sample represented in the West "small parties" out to define "Turkey Happy with Disabled Party" experience is also included in the study. The main claim of the study is that political participation and representation are as important as issues such as the right to education, the right to health, and the problem of unemployment in the social integration of the disabled. It is the first of the results of the study that the human rights model, which is one of the models used to make sense of and explain the social place of the disabled, can be a starting point in the social integration of disabled citizens as well as its function. Because, other models act with a sense of meaning by associating disability and disabled people with concepts 
such as embarrassing, flawed and incompetent with a perspective that "othering". However, in the human rights model, it primarily considers the rights of persons with disabilities as human beings and their right to use them as their most natural initiative. While explaining the social place of disabled people, the human rights model, which is in contact with the dignity of humanity, makes it necessary for the disabled to speak up, raise the issues that concern them, and to be included in the decision-making processes on these issues, based on the idea that the social, which is one of our preassumptions, is ultimately political. This context constitutes the main element we propose in the study: to include Jellinek's "active status rights", which includes citizens' political participation rights, into the human rights model. The role of political parties in representative democracy, as a way of expressing themselves on the political ground, is undeniable in modern times. It is obvious that their main aim was to seize power from the moment when political parties first emerged. However, the emergence of parties, which are currently described as small parties, brought the function of parties to the agenda, such as voicing the values they defend on the political ground, without targeting only power. In this context, the other conclusion reached in the study will be the creation of a party that will defend the rights of the disabled and keep them on the agenda, both will serve the aforementioned current function of the party and contribute to the social integration of the disabled citizens by taking into account the social mobilization and socialization practices of the parties. Turkey Happy with Disabled Party, which was established in this direction, has dissolved itself due to financial insufficiencies according to official records. The closure lawsuit filed against the Turkey Happy with Disabled Party due to not participating in the elections twice in a row and its dissolution as a result of the congress decision before the lawsuit is concluded can be interpreted as a political resentment.

\section{Kaynakça / References}

Akbaş K. ve Şen, İ. G. (2013). Türkiye'de kadına yönelik pozitif ayrımcılık: kavram, uygulama ve toplumsal alglar. Anadolu Üniversitesi Sosyal Bilimler Dergisi Hukuk Fakültesi 20. Yil Özel Sayısı.

Bahçekapıll, N. (2009). Kilise hukukunda kaynak kavramı. Journal of Islamic Research, 2(3), 50-62.

Dahl, R. (2019). Demokrasi üzerine. (Çev. B. Kadıŏlu) İstanbul: Phoenix Yayınevi. 
Dotcheva, M. (2009). Çokkültürlülük. (Çev. T. A. Onmuş) İstanbul: İetişim Yayınları.

Duverger, M. (1974). Siyasi partiler. (Çev. E. Özbudun) Ankara: Bilgi Yayınevi.

Dünya Sağlık Örgütü (2011). Dünya engellilik raporu (Çev. Aile ve Sosyal Politikalar Bakanlığı), Ankara: Anıl Group Matbaa.

Ektaş, A. F. (2017). Ulusalüstü boyutlarıla engeli hakları ve engeli kişilerin hakları sözleşmesi. İstanbul: Onikilevha Yayıncllik.

Goodley, D. (2011). Disability studies: An interdisciplinary introduction. London: Sage.

Gönülaçan, A. (2016). Türkiye'de engelli istihdamı ve işverenlerin engelli istihdamına yönelik tutumları: Trabzon örneği. Yayınlanmamış Yüksek Lisans Tezi, Süleyman Demirel Üniversitesi, Isparta.

Gözler, K. (2019). Anayasa hukukuna giriş. Bursa: Ekin Basım Yayın Dağıtım.

Gözübüyük, A. Ş. (1998). Anayasa hukuku. Ankara: Turhan Yayıncılık.

Heywood, A. (2007). Siyaset. (Ed. B. Kalkan) Ankara: Adres Yayınları.

Heywood, A. (2015). Siyasetin temel kavramları. (Çev. H. Özler) Ankara: Adres Yayınları.

https://en.wikipedia.org/wiki/Politics of the Netherlands\#: :text=The\%20major $\% 20$ political $\% 20$ parties $\% 20$ are,centre $\% 2$ Dright $\% 20$ Christian $\% 20$ democratic\%20party

https://web.archive.org/web/20160527053434/https://www.tbmm.gov.tr/kutuphane/siyasi partiler.html

https://www.resmigazete.gov.tr/eskiler/2005/02/20050208-24.htm

https://www.resmigazete.gov.tr/eskiler/2009/07/20090714.htm

https://www.tbmm.gov.tr/kutuphane/siyasi partiler.html

https://www.ailevecalisma.gov.tr/media/57045/istatistik_bulteni_agustos2020.pdf

https://biruni.tuik.gov.tr/yayin/views/visitorPages/index.zul

https://www.un.org/development/desa/disabilities/convention-on-the-rights-of-persons-with-disabilities/the-10th-anniversary-of-the-adoption-of-conventionon-the-rights-of-persons-with-disabilities-crpd-crpd-10.html

https://www.who.int/health-topics/disability\#tab=tab_1

https://meydan.org/2014/12/21/siyasi-tarihin-en-tuhaf-partileri-ve-e-parti-ilyas-seyrek/

Jellinek, G. (1913). L' Etat Modern et son droit, Cilt II, Paris, 51-57.

Kanter, A. S. (2003). The globalization of disability rights law. Syracuse Journal of International Law and Commerce, 30 Syracuse J. Int'1 L. \& Com.

Kapani, M. (1981). Kamu hürriyetleri. Ankara: AÜHF Yayınları.

Karataş, K. ve Oran, B. (2007). Engelliler: siyasetin periferinde kalanlar. Ufkun Ötesi Bilim Dergisi 7(2), 4-19. 
Kolat, S. (2009). Avrupa Birliği sosyal politikası çerçevesinde özürlülere yönelik ayrımcllıla mücadele ve Türkiye'deki yansımaları. (Yayınlanmamıs Uzmanlık Tezi, T.C. Başbakanlık Özürlüler İdaresi Başkanlığı), Ankara.

Kökkaya, Z. (2006). Avrupa Birliği yolunda Türkiye'de özürlü insanlarn ekonomik ve sosyal hakları. (Yayınlanmamış Yüksek Lisans Tezi, Bilgi Üniversitesi, SBE), İstanbul.

Meşe, İ. (2014). Engelliliği açıklayan sosyal model nedir? Sosyal Politika Çalışma Dergisi, 33, 79-92.

Miller, D. (1995). Blackwell'in siyasal düşünce ansiklopedisi. (Çev. B. Peker ve N. Kuraç) Ankara: Ümit Yayıncilı.

Mouffe, C. (2001). Demokratik paradoks. (Çev. A. C. Aşkın) Ankara: Epos Yayınları.

Oliver, M. (2013). The social model of disability: thirty years on, Disability\&Society 7(28) 1024-1026.

Orhan, S. (2015). Türkiye'de engellilerin bilinç düzeyi: engellilere sunulan istihdam hakları üzerinden bir araştırma. Bilgi Sosyal Bilimler Dergisi, 1, 73-98.

Örs, B. (2006). Siyasal temsil. İstanbul Üniversitesi Siyasal Bilgiler Fakültesi Dergisi, No:35.

Öztürk, A. (2020). Egemenliğin cumhuriyetçi yapısökümü: Machiavelli, Rousseau ve ulus devlet. Muhafazakâr Düşünce Dergisi. 58. 85-106.

Sayınta, D. (2014). Siyasal Temsil Üzerine Temel Belirlemeler. 15 Aralık 2020 tarihinde https://ayrintidergi.com.tr/siyasal-temsil-uzerine-temel-belirlemeler/ adresinden erişilmiştir.

Schnapper, D. (2005). Öteki ile ilişki. (Çev. A. Sönmezay) İstanbul: İstanbul Bilgi Üniversitesi Yayınlan.

Seyyar, A. (2015). Dünya'da ve Türkiye'de engelli dostu sosyal politikalar. İstanbul: Rağbet Yayınları.

Şişman, Y. (2012). Özürlülük alanında kullanılan kavramlar üzerine genel bir değerlendirme. Sosyal Politika Çalışmaları, 7 (28), 69-85.

Taşçı, F. (2018). Sosyal politikada dezavantajlı gruplar: tarih, yaklaşım ve uygulama. İstanbul: Kaknüs Yayınevi.

Türkiye Özürlüsü ile Mutludur Partisi Tüzük ve Programı (Parti Programı). (1996).

\section{Kaynakça Bilgisi / Citation Information}

Eraslan, E. ve Coşgun, M. (2020). Engellilerin toplumsal entegrasyonunda siyasal temsil üzerine bir deneme: Türkiye özürlüsü ile mutludur partisi. OPUS-Uluslararası Toplum Araştırmalan Dergisi, 17(38), 5764-5790. DOI: 10.26466/opus.891666. 